\title{
A Comparison of the Esterase and Catalase Zymograms of Fusarium Species with Special Reference to the Classification of a Causal Fungus of Fusarium Leaf Spot of Rice
}

\author{
Nobuaki Matsuyama* and Satoshi Wakimoto* \\ 松山宣明*・脇本 哲*：Fusarium 属菌とくにイネ褐色葉枯病菌分類の為の \\ エステラーゼ, カタラーゼザイモグラムの比較
}

\begin{abstract}
The causal agent of Fusarium leaf spot of rice (Kasshokuhagare-byo) was identified as Fusarium nivale (pink snow mold) in 1970, however, there are still some objections. To clarify this problem zymograms of non-specific esterase and catalase excreted by the causal fungi were compared. A preliminary comparison of various formae speciales of $F$. oxysporum and $F$. solani showed that the zymograms are species specific and useful for identification and taxonomy of Fusarium species. The zymograms of the leaf spot of rice were strikingly different from those of $F$. nivale causing typical pink snow mold. Differences were also observed between $F$. nivale from pink snow mold and that from various graminaceous plants in summer. The significance of $z y$ mogram diversity in the taxonomy of Fusarium species and the classification of the leaf spot fungus of rice were discussed.
\end{abstract}

(Received July 1, 1977)

\section{Introduction}

There are many etiological studies on Fusarium leaf spot disease of rice 10 13,22). In 1970 the causal fungus was identified as Fusarium nivale (Micronectriella nivalis) and in 1975 Fusarium nivale f. sp. graminicola and Micronectoriella nivalis were proposed as new names ${ }^{21)}$. However, Naito and Koshimizu ${ }^{22}$ objected to this nomenclature by morphological and physiological diversity.

Recently, the increasing usefulness of protein spectra and zymograms from gel electrophoresis have been emphasized $2,4 \sim 9,15 \sim 20,24)$. Although the taxonomy of plant pathogenic fungi depends on morphological and pathological criteria, physiological markers are useful when these markers are correlated with the major criteria. Matsuyama and Kozaka ${ }^{15}$ and Matsuyama, Kato and Yamaguchi ${ }^{16}$ ) studied the electrophoretic zymograms and reported their usefulness in differentiating Pyricularia species. In this experiment, esterase and catalase zymograms of various formae speciales of Fusarium oxysporum and $F$. solani were compared to find out whether they could be correlated with morphological criteria. Then zymograms of Fusarium leaf spot fungus of rice and $F$. nivale were compared. A preliminary report has already appeared ${ }^{18)}$. 


\section{Materials and Methods}

Isolates. Fourteen isolates of Fusarium oxysporum, ten of $F$. solani, three of $F$. nivale isolated in the spring from typical pink snow mold of barley, nine of $F$. nivale isolated in the summer from various graminaceous plants and nine of Fusarium leaf spot fungus of rice (Kasshokuhagare-byo) were used in this experiment. The details of each fungus are presented in Table 1.

Culturing. Each isolate was cultured on a shaker in $100 \mathrm{ml}$ of liquid synthetic medium supplemented $0.5 \%$ yeast extract for 9 days at $23 \mathrm{C}$ and $25 \mathrm{C}$ (F. oxysporum, F. solani).

Enzymes. Two volumes of cold acetone were added to chilled culture filtrates $(100 \mathrm{ml})$. The precipitates were collected by centrifugation at $3,200 \times \mathrm{g}$ for $10 \mathrm{~min}$. The supernatant was discarded and remained acetone was eliminated in vacuo. The pellets were stored in deep freezer until needed. For electrophoresis the precipitates were dissolved in $1 \mathrm{ml}$ of $1 / 60 \mathrm{M}$ phosphate buffer ( $\mathrm{pH} \mathrm{7.4)} \mathrm{containing} 12.5 \%$ glucose.

Thin layer electrophoresis. Nitto GE (acrylamide $92 \%$ and ethyleneurea bisacrylamide $8 \%$ ) was used as a supporting medium with DMAPN (dimethylamino propionitrile) and ammonium persulfate as catalysts. A $4 \%$ gel was used with a discontinuous buffer system (Gel buffer : $0.038 \mathrm{M}$ Trishydroxymethylaminomethane$0.0026 \mathrm{M}$ citric acid $\mathrm{pH} 8.8$, Electrode buffer : $0.3 \mathrm{M}$ boric acid $-0.05 \mathrm{M} \mathrm{NaOH} \mathrm{pH}$ 8.2). Ten $\mu$ l of each sample was poured into the gel slots. Electrophoresis was carried out at ca. $5 \mathrm{C}$ for about $100 \mathrm{~min}$ at constant $130 \mathrm{~V}$.

Detection. Non-specific esterase isozymes were detected on the gel with $0.1 \%$ Fast violet B salt and $0.05 \%$ 1- or 2 -naphthylacetate in $1 / 60 \mathrm{M}$ phosphate buffer ( $\mathrm{pH}$ 6.8). Catalase isozymes were detected with $1 \% \mathrm{H}_{2} \mathrm{O}_{2}$ in acetate buffer ( $\mathrm{pH}$ 4.7). Each isozyme was clearly detected as zone with small bubbles.

\section{Results}

\section{Esterase zymograms of $F$. oxysporum and $F$. solani}

All zymograms of various formae of $F$. oxysporum resemble each other. The esterase zymograms were very simple and the active isozyme was detected around Ef 0.35 (Fig 1, 2). Small differences in Ef value were observed between f. sp.

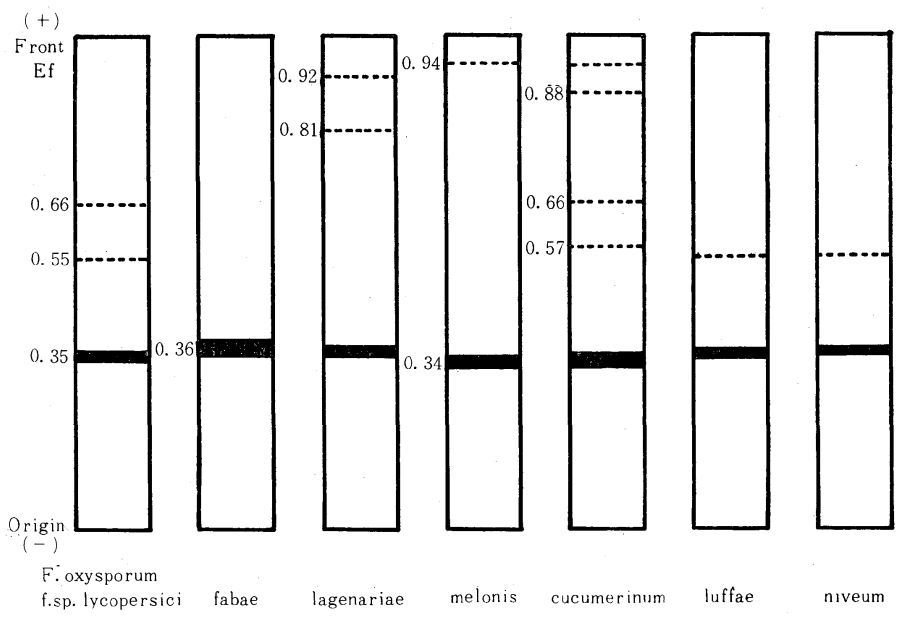

Fig. 1. Diagrammatic reprsentation of esterase zymograms of Fusarium oxysporum. Common isozyme around Ef 0.35 was observed. 
Ann. Phytopath. Soc. Japan 43 (4). November, 1977

Table 1. The list of the isolates used in this experiment

\begin{tabular}{|c|c|c|c|c|c|}
\hline Fusarium spp. & Isolate & Host & Place & Date & Source (Collectors) \\
\hline $\begin{array}{l}\text { Fusarium sp. } \\
\text { (Fusarium leaf } \\
\text { spot of rice) }\end{array}$ & $\begin{array}{l}F-11 \\
F-21 \\
F-41 \\
F-51 \\
F-75 \\
F-92 \\
F-121 \\
F-183 \\
F-221\end{array}$ & $\begin{array}{l}\text { Rice } \\
\text { "/ } \\
\text { " } \\
\text { " } \\
\text { " } \\
\text { "1 } \\
\text { " } \\
\text { " } \\
\text { " }\end{array}$ & $\begin{array}{l}\text { Okayama } \\
\text { Aichi } \\
\text { Fukuoka } \\
\text { Saga } \\
\text { Shizuoka } \\
\text { Iwate } \\
\text { Miyazaki } \\
\text { Hokkaido }\end{array}$ & 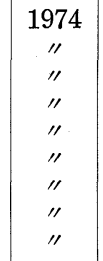 & $\begin{array}{l}\text { Yamaguchi and Ito (NIAS) } \\
\text { " } \\
\text { " } \\
\text { " } \\
\text { " } \\
\text { " } \\
\text { " } \\
\text { " }\end{array}$ \\
\hline $\begin{array}{l}F \text {. nivale } \\
\text { (From various } \\
\text { plants in } \\
\text { summer) }\end{array}$ & $\begin{array}{l}\text { IFO-7435 } \\
\text { IFO-7436 } \\
\text { IFO-7442 } \\
\\
\text { FNW } \\
\text { FNA } \\
\text { FNB } \\
\text { FNAB } \\
\text { FNR } \\
\text { Fn-5065 }\end{array}$ & $\begin{array}{l}\text { Barley } \\
\text { Wheat } \\
\text { Rescue } \\
\text { grass } \\
\text { Wheat } \\
\text { Agropyron } \\
\text { Barley } \\
\text { Agropyron } \\
\text { Rye } \\
\text { Barley }\end{array}$ & $\begin{array}{l}\text { Chiba } \\
\text { " } \\
\text { " } \\
\text { Tochigi } \\
\text { " } \\
\text { "1 } \\
\text { "1 } \\
\text { " }\end{array}$ & $\begin{array}{c}1957,5 \\
1957,6 \\
1959,5 \\
1976,6 \\
\prime \prime \\
\prime \prime \\
\prime \prime \\
1 " \\
1975,6\end{array}$ & $\begin{array}{c}\text { Yokoyama (IF), Nishihara } \\
\text { " } \\
\text { Yamaguchi (NIAS) } \\
\text { " } \\
\text { " } \\
\text { Nishihara (NGRI) }\end{array}$ \\
\hline $\begin{array}{l}F . \text { nivale } \\
\text { (Pink snow } \\
\text { mold) }\end{array}$ & $\begin{array}{l}\text { Fn-1 } \\
\text { Fn-2 } \\
\text { Fn-3 }\end{array}$ & $\begin{array}{c}\text { Barley } \\
\quad \prime \prime \\
\prime \prime\end{array}$ & $\begin{array}{l}\text { Hokkaido } \\
\text { (Shari) } \\
\text { (Bihoro) } \\
\text { (Kitami) }\end{array}$ & $\begin{array}{c}1975,4 \\
\prime \prime \\
\prime \prime\end{array}$ & $\begin{array}{c}\text { Tsuboki, Yamaguchi (NIAS) } \\
\text { " } " \text { " }\end{array}$ \\
\hline $\begin{array}{l}\text { F. oxysporum } \\
\text { f. sp. } \\
\text { lycopersici } \\
\text { fabae } \\
\text { luffae } \\
\text { phaseoli } \\
\text { lagenariae } \\
\text { niveum } \\
\text { melonis } \\
\text { cucumerinum } \\
\text { fragariae } \\
\text { lini }\end{array}$ & $\begin{array}{l}\text { F-211 } \\
\text { SUF-803 } \\
\text { SUF-960 } \\
\text { SUF-888 } \\
\text { SUF-363 } \\
\text { SUF-672 } \\
\text { SUF-797 } \\
\text { SUF-366 } \\
\text { KF-320 } \\
\text { F } 1-8-1 \\
\text { KF-326 } \\
\text { F } 1-4-1 \\
\text { KF-328 } \\
\text { F } 1-6-1\end{array}$ & $\begin{array}{l}\text { Tomato } \\
\text { Broad Bean } \\
\text { Dishcloth } \\
\text { gourd } \\
\text { Kidney } \\
\text { Bean } \\
\text { White flowered } \\
\text { gourd } \\
\text { Watermelon } \\
\text { melon } \\
\text { "' } \\
\text { Cucumber } \\
\text { "' } \\
\text { Strawberry } \\
\text { Hemp }\end{array}$ & & & $\begin{array}{l}\text { Saito (Kochi Agr. Exp. stn.) } \\
\text { Matsuo (Shinshu Univ.) } \\
\text { via Kiso (Kurume Br. VORS) } \\
\text { " } \\
\qquad, \\
\text { " " } \\
\text { " } \\
\text { Kiso (Kurume Br. VORS) } \\
\text { NIAS, Matsuo (Shinshu Uviv.) } \\
\text { Kiso (Kurume Br. VORS) } \\
\text { NIAS, Matsuo (Shinshu Univ.) } \\
\text { Fujii, Kiso (Kurume Br. VORS) } \\
\text { NIAS }\end{array}$ \\
\hline $\begin{array}{l}\text { F. solani } \\
\text { f. sp. } \\
\text { mori }(\mathrm{MF}+) \\
\text { radicicola } \\
\text { (MF-) } \\
\text { robiniae } \\
\text { (MF-) } \\
(\mathrm{MF}+) \\
\text { xanthoxyli } \\
(\mathrm{MF}-) \\
(\mathrm{MF}+) \\
\text { phaseoli }\end{array}$ & \begin{tabular}{|l|} 
SUF-232 \\
SUF-208 \\
\\
SUF-578 \\
SUF-577 \\
\\
SUF-XV-1 \\
SUF-XV-23 \\
SUF-386
\end{tabular} & $\begin{array}{l}\text { Blacklocust } \\
\text { " } \\
\text { Xanthoxyum sp. } \\
\text { " } \\
\text { Kidney bean }\end{array}$ & & & $\begin{array}{l}\text { Matsuo (Shinshu Univ.) } \\
\text { " } \\
\text { " } \\
\text { " }\end{array}$ \\
\hline $\begin{array}{l}\text { pisi } \\
\text { "I } \\
\text { " }\end{array}$ & $\begin{array}{l}\text { SUF-II-7 } \\
\text { SUF-654 } \\
\text { F-1-10-1 }\end{array}$ & $\begin{array}{l}\text { Pea } \\
\prime \prime \\
\prime \prime\end{array}$ & & & $\begin{array}{l}\text { Matsuo (Shinshu Univ.) } \\
\text { via Kiso (Kurume Br. VORS) } \\
\text { NIAS, MATSUO (Shinshu Univ.) }\end{array}$ \\
\hline
\end{tabular}

note : NIAS : National Institute of Agricultural Sciences

VORS: Vegetables and Ornamental Crops Research Station

NGRI : National Grassland Research Institute

IF : Institute for Fermentation 


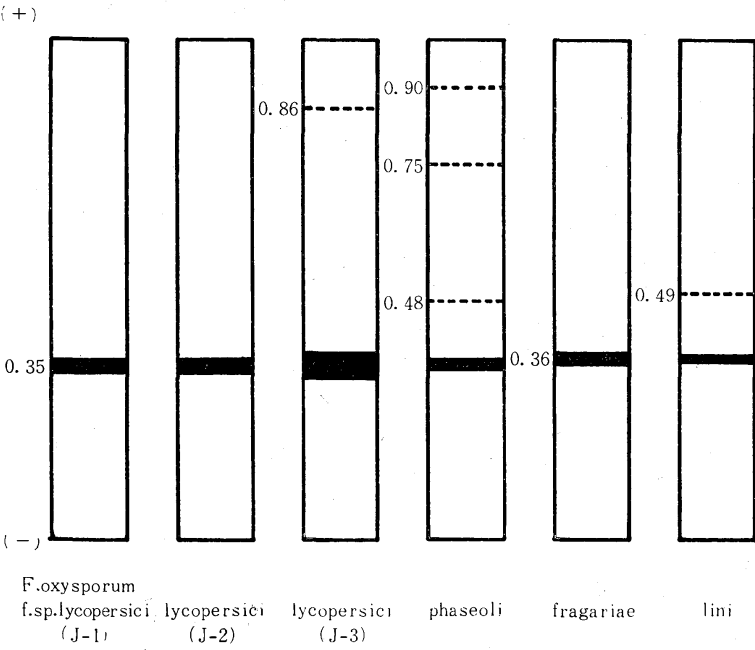

Fig. 2 Diagrammatic representation of esterase zymgrams of Fusarium oxysporum. J-1, 2,3 represent races of $\mathrm{f}$. sp. lycopersici.

lycopersici and other formae but no differences were observed among races $(\mathrm{J}-1, \mathrm{~J}-2, \mathrm{~J}-3)$.

The zymograms of $F$. solani were also simple. Though slight differences were observed for each forma, most isozymes were found around Ef 0.90 (Fig 3). These zymograms were distinctly different from those of $F$. oxysporum. The results show that the zymograms reflect the morphological classification. They also indicate that fungi which show the same zymogram could belong to the same species.

The esterase zymograms of Fusarium sp. isolated from the leaf spot of rice and $F$. nivale.

The zymograms of Fusarium sp. from rice were slightly more complex than those of $F$. oxysporum or $F$. solani. Isolates from various places in Japan showed almost same the zymograms (Fig 4). The isozyme at Ef 0.98 was a distinct marker for this fungus. This isozyme was undetectable without substrate and lost its activity on heating. Its electrophoretic mobility was great and it was resistant to eserine inhibition like arylesterase.

Fusarium nivale isolated in summer from various plants and in spring from a typical pink snow mold, also showed complex zymograms (Fig. 5,6). However, they were obviously different from those of the leaf spot fungus of rice. Differences were also observed between $F$. nivale isolated in summer and $F$. nivale from pink snow mold. The zymograms of both fungi were roughly similar, however, the Ef values were different.

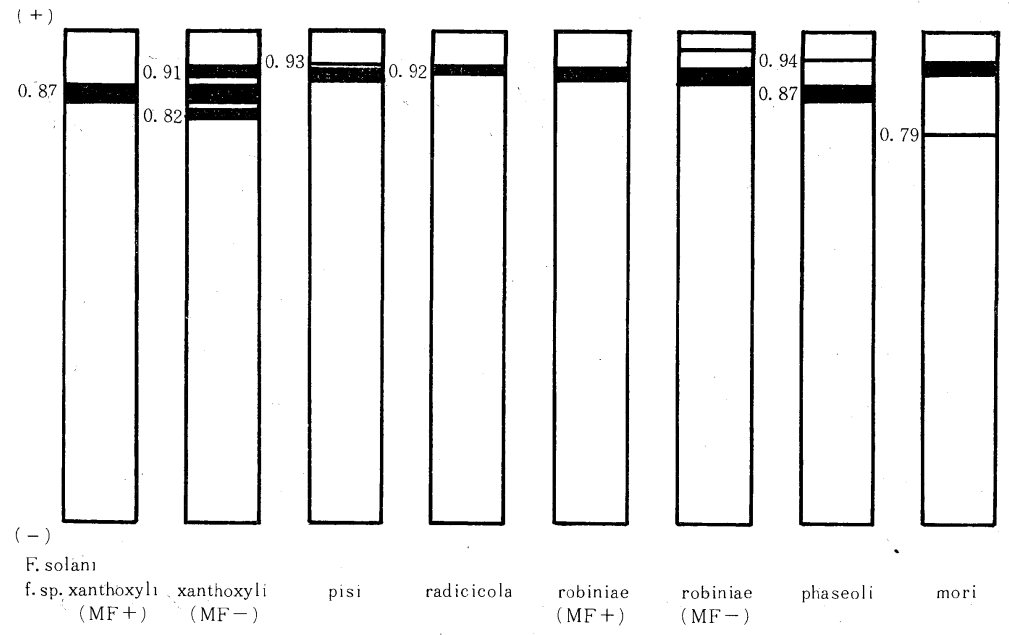

Fig. 3 Diagrammatic representation of esterase zymograms of Fusarium solani. Main isozymes were always detected around Ef 0.90 . 


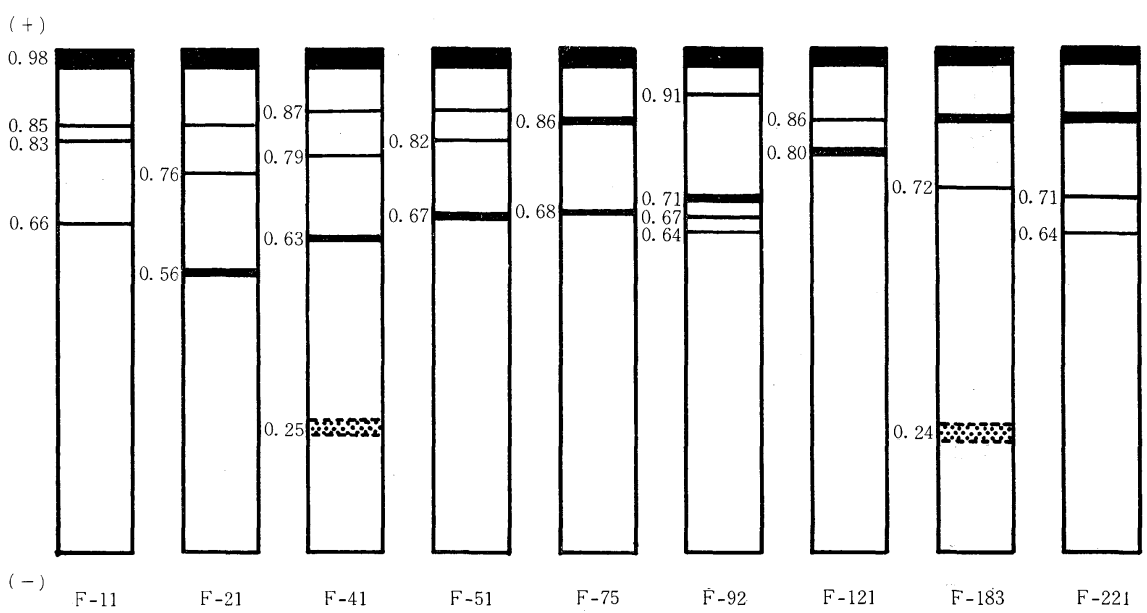

Fig. 4 Sites of esterase activity for nine isolates of Fusarium leaf spot fungus of rice. Ef 0.98 isozyme was commonly observed in this group.

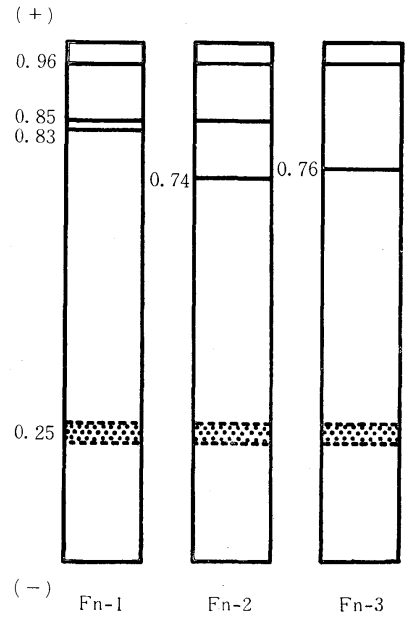

Fig. 5. Sites of esterase activity for three isolates of $F$. nivale isolated from pink snow mold of barley.

\section{Catalase zymograms}

Catalase zymograms were very simple and one or two isozymes were detected (Fig. 7). The Ef 0.55 isozyme has high activity and was only detected in the Fusarium leaf spot fungus of rice. Most isolates of this fungus also had the Ef 0.84 isozyme. While $F$. nivale isolated in summer also had the Ef 0.84 isozyme and $F$. nivale from pink snow mold had an obviously different isozyme at Ef 0.77. No catalase isozymes were detected in $F$. oxysporum and $F$. solani under these experimental conditions.

\section{Zymograms at various culture stages of the fungi}

A comparison of esterase and catalase zymograms at different culture stages was carried out. The zymograms varied according to the stage of growth and gave different patterns at early stages. However, almost same patterns were obtained from 6th to 11th day (Fig. 8). The isozyme at Ef 0.98 which was specific in the zymograms of Fusarium leaf spot fungus of rice appeared by 6 th day and was observed even 11 days after inoculation. The zymogram changes in catalase were also observed and steady zymogram was obtained from 6th to 11th day.

\section{Discussion}

Zymogram comparison, in spite of its limitations, could be a handy and reliable method for identification and taxonomy of fungi $\mathrm{i}^{2,4 \sim 9,15 \sim 20,24)}$. Matsuyama et $a l^{15}$ 18). stressed the usefulness of thin layer polyacrylamide gel electrophoresis for this purpose and its convenience in comparing many samples on same gel sheet.

Esterase zymograms were species specific in Pyricularia spp. ${ }^{16)}$. Araki and Suzuki ${ }^{2)}$ reported that the esterase zymograms of $F$. oxysporum f. sp. lycopersici and cucumerinum are different from that of niveum. Meyer and Renard ${ }^{20}$ compared $F$. oxysporum f. sp. melonis with $\mathrm{f}$. sp. elaeidis and failed to distinguish between 


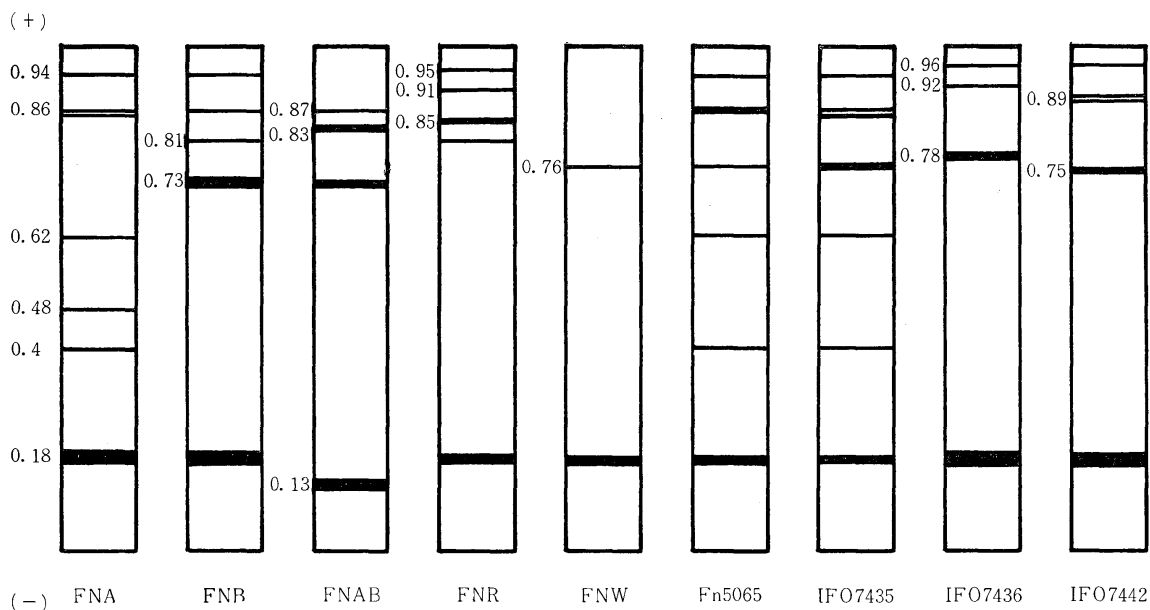

Fig. 6 Sites of esterase activity for nine isolates of $F$. nivale isolated from various graminaceous plants in summer. Common isozyme around Ef 0.18 was observed in every zymograms.

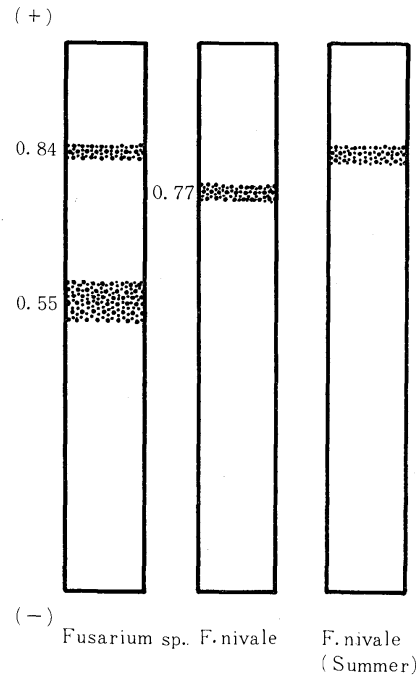

Fig. 7 Diagrammatic representation of catalase zymograms of Fusar. ium leaf spot fungus of rice (left), $F$. niv. ale from pink snow mold (middle) and $F$. nivale isolated in summer (right).

them. Our data on 10 formae of $F$. oxysporum showed a strong similarity among them. However, slight differences in Ef values of the marker isozyme were observed between $F$. oxysporum f. sp. lycopersici and the other formae. Though Fusarium oxysporum is a huge species and shows considerable variation in morphology and pathogenicity, the zymograms of each forma were quite similar.

The zymograms of each forma of $F$. solani were almost identical and were distinctly different from those of $F$. oxysporum. This result agrees with morphological and immunological observations ${ }^{3)}$. Thus, the usefulness and reliability of esterase zymograms for the taxonomy were confirmed by these results.

The causal fungus of the leaf spot of rice (Kasshokuhagare-byo) has long been studied by many workers 10 $\sim 13,22)$. But the identification of the fungus has been suspended because of its difficulties of inoculation.

Around 1967 this disease was epidemic in Japan. Kitani and Ohata ${ }^{12}$ ) reported that the causal fungus was morphologically same with the leaf blotch fungus of rice formerly identified as Rynchosporium oryzae Hashioka et Yokogi (Kumogata-byo) ${ }^{10)}$. However, they were uncertain if this fungus was really Rynchosporium sp.. In 1970 Koshimizu et $a l^{13}$ ) summarized earlier reports and concluded that the causal fungi of both diseases were the same and are Ascomycetes. In the same year this fungus was identified as Fusarium nivale (Micronectriella nivalis) ${ }^{26)}$. This name was listed formally as Fusarium nivale (Fries) Cesati f. sp. graminicola (Berkeley et Broome) Snyder et Hansen, Micronectriella nivalis (Schaffnit) Booth ${ }^{21)}$. Naito and Koshimizu ${ }^{22}$ recognized that this fungus was one of the Fusarium spp.. However, they have suspended if this fungus is $F$. nivale and Micronectriella sp. because of morphological and physiological diversity. They reported that the leaf spot fungus 


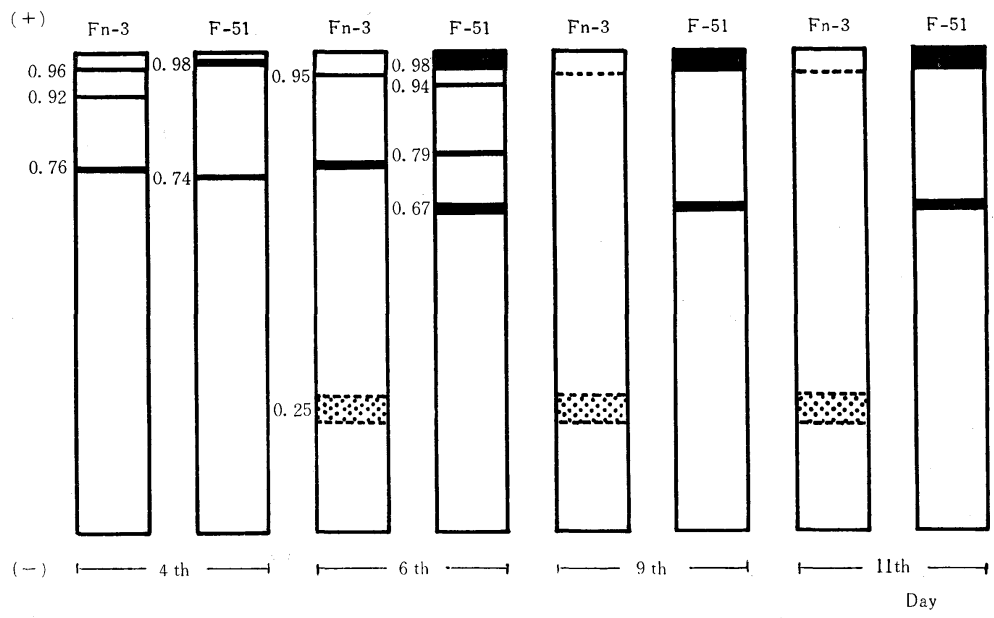

Fig. 8 Esterase profiles of Fusarium leaf spot fungus of rice (F-51) and $F$. nivale isolated from pink snow mold of barley (Fn-3) at various culture stages.

of rice seemed to have double walled asci and chlamydospore-like structures and that the optimal temperature for mycelial growth was higher than that of Fusarium nivale.

All isolates from diseased rice leaves from various parts of Japan showed almost identical zymograms and had the characteristic isozyme at Ef 0.98 . They form a distinct group that is quite different from $F$. nivale. Differences were also observed in catalase zymograms although one isozyme was common to the leaf spot fungus of rice and $F$. nivale isolated in the summer. This may mean that although these fungi are not the same, they may have an evolutionary relationship. The differences between zymograms support partly Naito and Koshimizu's observation ${ }^{22}$.

In 1940, it was reported that the causal fungus of pink snow mold (Fusarium nivale f. sp. graminicola) caused dark fleck on wheat leaves even in summer ${ }^{1)}$. Similar symptoms were also reported on various other plants in early and mid summer and isolates were identified as $F$. nivale ${ }^{23)}$. Some of these isolates were used in our studies. However, their esterase and catalase zymograms were different from those of $F$. nivale isolated from typical pink snow mold in early spring.

In earlier experiments with Pyricularia $\mathrm{spp}^{16)}$,, the zymogram differences were correlated with classification at the species level based on morphology and in this studies the same phenomenon was observed. The zymogram differences between the leaf spot fungus of rice and the two kinds of $F$. nivale seem to indicate diversity at the species level. However, the Snyder-Hansen system for Fusarium classification ${ }^{25}$ ) is reduced for convenience to only 8 species and 34 formae speciales instead of Wollenweber's 16 sections, 66 species, 57 varieties and 22 forms ${ }^{27)}$. Therefore, a single species sometimes involves several physiologically, and even morphologically, different isolates. Thus, different zymograms may not always mean different species in Fusarium. However, we can say that the leaf spot fungus of rice could not be same with $F$. nivale because of large diversity of zymograms. Fusarium nivale isolated in the summer and $F$. nivale isolated from typical snow mold in the spring might be in same species so far as the Snyder-Hansen system is concerned, but these two fungi are clearly not identical. Fusarium leaf blotch of various plants in summer is clearly different from the pink snow mold in winter. Further detailed mor- 
phological comparisons are needed.

Authors are grateful to Dr. T. Yamaguchi and Dr. M. Ito of Natl. Inst. Agric. Sci., Dr. T. Araki of Hokkaido Natl. Agric. Exp. Station., Dr. N. Nishihara of Natl. Grassland Res. Institute, Dr. A. Kiso of Kurume Branch of Vegetable and Ornamental crops Res. Station, Dr. T. Yokoyama of Institute for Fermentation and Prof. Dr. T. Matsuo of Shinshu University for their supplying of cultures and many advices. We also appreciate to Dr. P. R. Day of Conn. Agric. Exp. Station, USA for his critically reviewing the manuscript.

\section{References}

1. Asuyama, H. (1940) Ann. Phytopath. Soc. Japan $10: 51-54$.

2. Araki, T. and Suzuki, N. (1966) Ann. Phytopath. Soc. Japan $32: 73$ (abstr.)

3. Araki, T. (1974) Presented at the 7 th meeting on soil borne disease (Ibaraki, Japan)

4. Clare, B. G. (1963) Nature 200, 803-804.

5. Clare, B. G. and Zentmyer, G. A. (1966) Phytopath. Z. $13: 84-94$.

6. Durbin, R. D. (1966) Nature $210: 1186-1187$.

7. Gill, H. S. and Powell, D. (1968) Phytopath. Z. $63: 23-29$.

8. Hall, R. (1967) Aust. J. Biol. Sci. $20: 419-428$.

9. Hall, R., Zentmyer, G. A. and Erwin, D. C. (1969) Phytopathology $59: 770-774$.

10. Hashioka, Y. and Ikegami, H. (1955) Jubilie publication of the 60th birthday of Prof. Tochinai and Fukushi, 45-61.

11. Inoue, Y. and Takeuchi, S. (1957) Preliminary reports of Lab. Plant protec., TohkaiKinki natn., agric. Exp. Stn. (S. 31) 64-70.

12. Kitani, K. and Ohata, K. (1968) Papers of Lab. Plant protec., Shikoku natn. agric. Exp. Stn. (S. 42) 61-69.

13. Koshimizu, Y., Naito, H. and Yanagita. K. (1970) Bull. Tohoku natn. agric. Exp. Stn. $39: 111-135$.

14. Matsuo, T. (1972) Rev. Plant Protec. Res. $5: 34-45$.

15. Matsuyama, N. and Kozaka, T. (1971) Ann. Phyttopath. Soc. Japan $37: 259-265$.

16. Matsuyama, N., Kato, H. and Yamaguchi, T. (1975) Ann. Phytopath. Soc. Japan 42 : 110 (abstr.).

17. Matsuyama, N., Kato, H. and Yamaguchi, T. (1977) Ann. Phytopath. Soc. Japan 43: $419-425$.

18. Matsuyama, N. and Wakimoto, S. (1977) Ann. Phytopath. Soc. Japan 43: 317

19. Meyer, J. A., Garber, E. D. and Schaeffer, S. G. (1964) Bot. Gaz. $125: 298-300$.

20. Meyer, J. A. and Renard, J. L. (1969) Phytopathology $59: 1409-1411$.

21. Misawa, T. et al (1975) Common names of economic plant diseases in Japan Vol. 1 (Second Edition), Phytopath. Soc. Japan

22. Naito, H. and Koshimizu, Y. (1974) Ann. Phytopath. Soc. Japan $40: 319-328$.

23. Nishihara, N. (1958) Ann. Phytopath. Soc. Japan $23: 33$ (abstr.).

24. Pelletier, G., and Hall, R. (1971) Can. J. Bot. $49: 1293-1297$.

25. Snyder, W. C. and Hansen, H. N. (1940) Amer. J. Bot. $27: 64-67$.

26. Tominaga, T. (1970) Ann. Phytopath. Soc. Japan $36: 367$ (abstr.).

27. Wollenweber, H. W. and Reinking, O. A. (1935) Die Fusarien. Paul Parey, Berlin 355. 
和 文 摘 要

Fusarium 属菌とくにイネ褐色葉枯病菌分類の為の

エステラーゼ，カタラーゼザイモグラム比較

松山宣明・脇本 哲

イネ褐色葉枯病菌は1970年 F. nivale（ムギ類紅色雪腐病菌）と同定されたが形態の部分的相違，生理的性 質の違いから異論もみられる。乙の問題を明らかにする為，前報においてその実用性が認められた非特異的 エステラーゼ，カタラーゼのザイモグラム比較を行なった。まず予備試験として f. sp. を異にする $F . o x y s p$. orum, F. solani の此較を行なった結果，種のレベルでザイモグラムが明らかに異っており，乙の手法が Fusarium 属菌の分類同定にも利用出来るととが確認された。イ不褐色葉枯病菌, ムギ類紅色雪鹰病菌 $(F$. nivale), 夏期に各種梖物から分離され F. nivale 上同定されている菌株のザイモグラムは互に明確な違いを 示した。これらの結果に基き，Fusarium 属菌の分類に於てザイモグラムの差違があつ意義，イネ褐色葉枯 病菌の所属について論議它加えた。 